\title{
Allyl Sulfides Are Privileged Substrates in Aqueous Cross-Metathesis: Application to Site-Selective Protein Modification
}

\author{
Yuya A. Lin, Justin M. Chalker, Nicola Floyd, Gonçalo J. L. Bernardes, and Benjamin G. Davis* \\ Chemistry Research Laboratory, Department of Chemistry, University of Oxford, 12 Mansfield Road, \\ Oxford OX1 3TA, U.K. \\ Received April 9, 2008; E-mail: ben.davis@chem.ox.ac.uk
}

Olefin metathesis has become a mainstay in organic synthesis. ${ }^{1}$ Cross-metathesis (CM), however, is largely underdeveloped compared to ring closing metathesis (RCM) and ring opening metathesis polymerization since $\mathrm{CM}$ does not have the entropic driving force of RCM and is complicated by self-metathesis. ${ }^{2}$ Our group has a long-term interest in site-selective chemical modification of proteins in an effort to study and modulate their function. ${ }^{3}$ Olefin metathesis is an attractive way to install these protein modifications through a stable carbon-carbon bond. Indeed, incorporation of olefins into proteins has been possible for nearly a decade, ${ }^{4}$ but metathesis at such residues has not been realized. Despite recent reports of olefin metathesis in water, the current benchmark for homogeneous aqueous $\mathrm{CM}$ is the self-metathesis of simple unsaturated alcohols such as allyl alcohol. ${ }^{5,6}$ The limited examples revealed to date highlight the challenges for aqueous $\mathrm{CM}$ and the gap in substrate complexity that must be bridged to carry out metathesis on protein surfaces.

To determine the viability of $\mathrm{CM}$ on protein surfaces, simple amino acid models were investigated. Substrates were selected on the basis of potential incorporation into proteins. A reasonable starting point was homoallylglycine (Hag) since its in vivo incorporation by methionine auxotrophic Escherichia coli is known. ${ }^{4}$ Hoveyda-Grubbs second generation catalyst $\mathbf{1}^{7}$ was selected since it is phosphine free and therefore more likely to be compatible with protein disulfides than other conventional catalysts. A simple test metathesis with allyl alcohol 2 was carried out to assess the reactivity of Hag derivative 3. At the outset, we limited ourselves to temperatures generally compatible with proteins $(\leq 37$ ${ }^{\circ} \mathrm{C}$ ) and made no effort to exclude oxygen. Since $\mathbf{1}$ is not freely soluble in water, it was added as a solution in ${ }^{t} \mathrm{BuOH}$. Unfortunately, despite repeated attempts, only starting material 3 was recovered (Table 1, Entry 1). We turned next to cysteine derivatives since incorporation into proteins should be possible by either chemical or genetic means if they proved reactive in CM. Remarkably, $S$-allylcysteine (Sac) derivative $\mathbf{4}$ underwent metathesis with allyl alcohol (Entry 2), affording the CM product in $56 \%$ isolated yield (74\% based on recovered 4 ). This result was noteworthy given the number of instances where thioethers were detrimental to rutheniumbased metathesis catalysts. ${ }^{8}$ The metathesis was also efficient with allyl homocysteine 5 and bisamide Sac derivative 6. Yet when the alkene was extended by one or two methylene units from the sulfur center, only allyl alcohol self-metathesis was observed along with recovered starting material (Entries 5 and 6). Other allylheteroatom substrates were screened, but allyl sulfides remained the most efficient metathesis substrates under the conditions employed (Entries 7-13).

While the self-metathesis of allyl sulfides has been carried out in organic solvents, the efficiency relative to other heteroatom or hydrocarbon analogues was not apparent and yields were highly dependent on the catalyst used. ${ }^{9}$ We suggest that the enhanced reactivity of allyl sulfides may be a consequence of sulfur
Table 1. Heteroatom Effects in Aqueous Cross-Metathesis

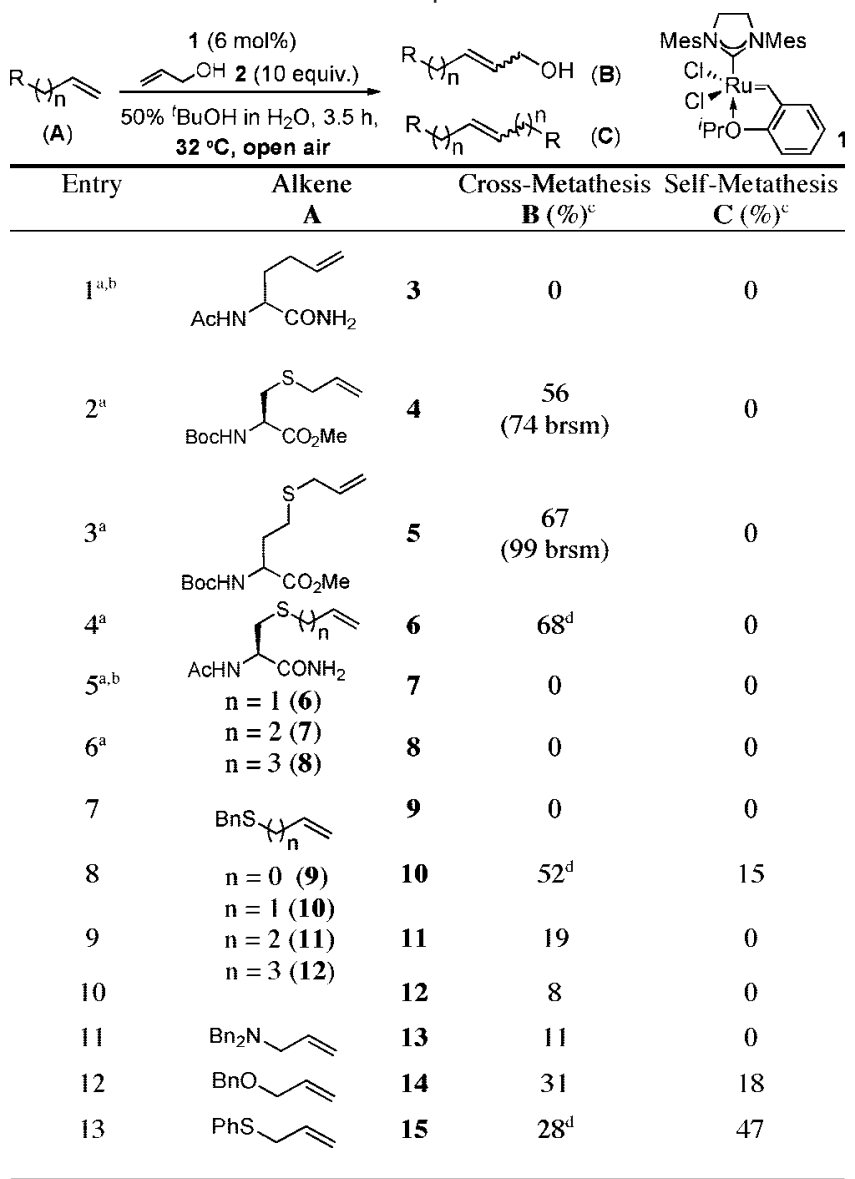

${ }^{a} 8 \mathrm{~mol} \%$ of $1,2.5 \mathrm{~h} .{ }^{b} 30 \%{ }^{t} \mathrm{BuOH} / \mathrm{H}_{2} \mathrm{O} .{ }^{c}$ Isolated. ${ }^{d}>98 \%$ conversion

Scheme 1. Sulfur Assisted Cross-Metathesis of Allyl Sulfides
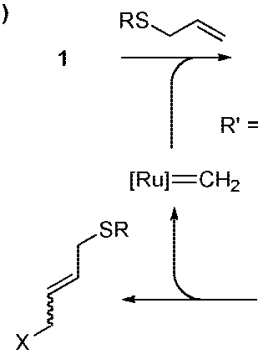

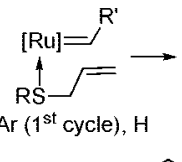

[Ru]
(1) 
butenyl and pentenyl sulfides (e.g., 7-8 and 11-12) may be attributed to the formation of unproductive five- or six-membered chelates, respectively (Scheme 1b). ${ }^{8 \mathrm{~d}, 12}$ Attempts to isolate such species, however, were unfruitful. ${ }^{13}$

The results in Table 1 led us immediately to pursue Sac incorporation into proteins. Conveniently, an efficient chemical route to thioether modified proteins was recently developed in our laboratory. ${ }^{14}$ The reaction of $O$-mesitylenesulfonylhydroxylamine (MSH) with cysteine rapidly generates dehydroalanine which can then be reacted with a thiol nucleophile. Application of this methodology to a single cysteine mutant of the serine protease subtilisin Bacillus lentus (SBL) allowed efficient incorporation of Sac into the protein (eq 1).

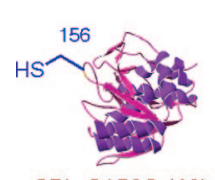

SBL-S156C (16)

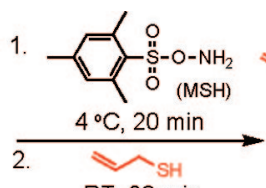

$\mathrm{RT}, 30 \mathrm{~min}$

One-pot, $>95 \%$ conversion

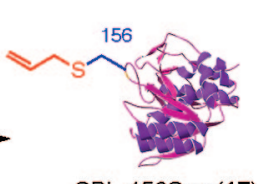

SBL-156Sac (17)
Ready access to Sac on protein surfaces enabled us to take advantage of the unique reactivity of allyl sulfides in CM. Initial attempts were carried out simply by adding excess $\mathbf{1}$ and $\mathbf{2}$ to a solution of SBL-156Sac 17 in $50 \mathrm{mM}$ sodium phosphate (pH 8.0) (Table 2). LC-MS analysis revealed largely unreacted $\mathbf{1 7}$, even after prolonged reaction time. Nevertheless, we were intrigued by a minor, yet significant, MS signal that appeared upon the addition of $\mathbf{1}$ to $\mathbf{1 7} .{ }^{15}$ We speculated this species might be a metalloprotein derived from metathesis with $\mathbf{1}$, inactive in $\mathrm{CM}$ due to nonproductive chelation of side chains to ruthenium. $\mathrm{MgCl}_{2}$ was added to the reaction buffer with the intention of disrupting any such nonproductive chelation to ruthenium. Fürstner used $\mathrm{Ti}\left(\mathrm{O}^{i} \mathrm{Pr}\right)_{4}$ in a similar fashion to disrupt nonproductive chelation in RCM. ${ }^{12 \mathrm{c}}$ Gratifyingly, when $\mathrm{MgCl}_{2}$ was included in the buffer, CM with allyl alcohol proceeded to $>90 \%$ conversion at room temperature (Table 2, Entry 2). ${ }^{15}$ To verify that the effect was due to $\mathrm{Mg}^{2+}$ and not chloride, $\mathrm{NaCl}$ was used as additive (Table 2, Entry 3): no CM was observed

Table 2. Cross-Metathesis on SBL-156Sac

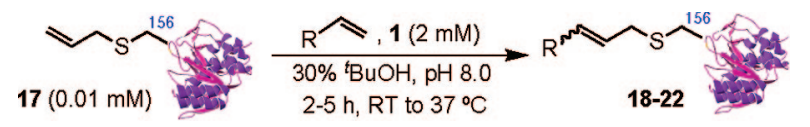

\begin{tabular}{|c|c|c|c|c|c|}
\hline Entry & Alkene (mM) & $\begin{array}{l}\text { Additives } \\
(\mathrm{mM})\end{array}$ & Temp. & Prod. & $\begin{array}{c}\text { Conversion } \\
(\%)^{\mathrm{a}}\end{array}$ \\
\hline 1 & $2(100)$ & None & RT & - & 0 \\
\hline 2 & $2(100)$ & $\begin{array}{l}\mathrm{MgCl}_{2} \\
(100)\end{array}$ & RT & 18 & $>90$ \\
\hline 3 & $2(100)$ & $\begin{array}{l}\mathrm{NaCl} \\
(100)\end{array}$ & RT & - & 0 \\
\hline $4^{b}$ & & $\begin{array}{c}\mathrm{MgCl}_{2} \\
(80)\end{array}$ & $37^{\circ} \mathrm{C}$ & 19 & 50 \\
\hline $5^{b}$ & & $\begin{array}{l}\mathrm{MgCl}_{2} \\
(130)\end{array}$ & $37^{\circ} \mathrm{C}$ & 20 & 60 \\
\hline $6^{c}$ & $25(75)$ & $\begin{array}{l}\mathrm{MgCl}_{2} \\
(160)\end{array}$ & $37^{\circ} \mathrm{C}$ & 21 & 55 \\
\hline $7^{\mathrm{c}}$ & $26(6)^{3}$ & $\begin{array}{c}\mathrm{MgCl}_{2} \\
(130)\end{array}$ & $37^{\circ} \mathrm{C}$ & 22 & 60 \\
\hline
\end{tabular}

${ }^{a}$ Determined by LC-MS. ${ }^{b}$ First hour at rt. ${ }^{c}$ First $2 \mathrm{~h}$ at RT. without $\mathrm{Mg}^{2+}$. Importantly, 18 was an active peptidase and not denatured over the modification sequence. ${ }^{15}$ Biologically and therapeutically relevant glycosylation ${ }^{16}$ and PEGylation ${ }^{17}$ were also achieved by CM (Entries 4-7).

Finally, efforts in genetic incorporation of allyl sulfide containing amino acids are also underway to explore their scope as tags for $\mathrm{CM}$ on proteins. Genetic installation ensures stereochemical homogeneity of the protein backbone and allows strategic flexibility. This approach was tested using the B834 E. coli strain, a methionine (Met) auxotroph. ${ }^{4,15}$ Low level Sac incorporation was verified by MS-MS analysis in a single Met mutant of Sulfolobus solfataricus $\beta$-glycosidase expressed in Met-depleted media with Sac as Met surrogate. $^{15}$

In conclusion, we have shown that allyl sulfides are effective substrates in aqueous CM through the use of catalyst 1. Taking advantage of the enhanced reactivity of allyl sulfides in CM, we were able to post-translationally modify proteins via carbon-carbon bond formation. This work is an addition to a growing interest in metal-mediated protein modifications ${ }^{18}$ and a new standard in substrate sensitivity and complexity in olefin metathesis.

Acknowledgment. We gratefully acknowledge the Rhodes Trust (J.M.C.), the International AIDS Vaccine Initiative (N.F.) and FCT, Portugal (G.J.L.B.), for financial support.

Supporting Information Available: Full experimental details and compound characterization. This material is available free of charge via the Internet at http://pubs.acs.org.

\section{References}

(1) (a) Grubbs, R. H Handbook of Metathesis; Wiley-VCH: Weinheim, Germany, 2003. (b) Hoveyda, A. H.; Zhugralin, A. R. Nature 2007, 450, 243-251. (c) Fürstner, A. Angew. Chem., Int. Ed. 2000, 39, 3012-3043.

(2) Connon, S. J.; Blechert, S. Angew. Chem., Int. Ed. 2003, 42, 1900-1923.

(3) Gamblin, D. P.; van Kasteren, S. I.; Chalker, J. M.; Davis, B. G. FEBS J. 2008, 4, 558-561.

(4) (a) Van Hest, J. C. M.; Tirrell, D. A. FEBS Lett. 1998, 428, 68-70. (b) Van Hest, J. C. M; Kiick, K. L.; Tirrell, D. A. J. Am. Chem. Soc. 2000, 122, 1282-1288.

(5) (a) Hong, S. H.; Grubbs, R. H. J. Am. Chem. Soc. 2006, 128, 3508-3509. (b) Jordan, J. P.; Grubbs, R. H. Angew. Chem., Int. Ed. 2007, 46, 51525155. (c) Binder, J. B.; Blank, J. J.; Raines, R. T. Org. Lett. 2007, 9, 48854888. (d) Gulajski, L.; Michrowaska, A.; Naroznik, J.; Kaczmarska, Z.; Rupnicki, L.; Grela, K. ChemSusChem 2008, 1, 103-109.

(6) For aqueous CM in heterogeneous media, see: (a) Mwangi, M. T.; Runge, M. B.; Bowden, N. B. J. Am. Chem. Soc. 2006, 128, 14434-14435. (b) Lipshutz, B. H.; Aguinaldo, G. T.; Ghorai, S.; Voigtritter, K. Org. Lett. 2008, 10, 1325-1328. (c) Gulajski, L.; Sledz, P.; Lupa, A.; Grela, K. Green Chem. 2008, 10, 271-274.

(7) Garber, S. B.; Kingsbury, J. S.; Gray, B. L.; Hoveyda, A. H. J. Am. Chem. Soc. 2000, 122, 8168-8179.

(8) (a) Armstrong, S. K.; Christie, B. A. Tetrahedron Lett. 1996, 37, 93739376. (b) Shon, Y.-S.; Lee, T. R. Tetrahedron Lett. 1997, 38, 1283-1286. (c) Mascareñas, J. L.; Rumbo, A. Castedo, L. J. Org. Chem. 1997, 62, 8620-8621. (d) Fürstner, A.; Seklel, G.; Kindler, N. Tetrahedron 1999, $55,8215-8230$.

(9) (a) Toste, F. D.; Chatterjee, A. K.; Grubbs, R. H. Pure Appl. Chem. 2002, 74, 7-10. (b) Spagnol, G.; Heck, M.-P.; Nolan, S. P.; Mioskowski, C. Org. Lett. 2002, 4, 1767-1770.

(10) Coordination depicted in the metallocyclobutane in Scheme 1a is based on X-ray analysis of related intermediates: Feldman, J.; Murdezek, J. S.; Davis, W. M.; Schrock, R. R. Organometallics 1989, 8, 2260-2265.

(11) Fürstner, A.; Langemann, K. Synthesis 1997, 792-803.

(12) (a) Fürstner, A.; Thiel, O. R.; Lehmann, C. W. Organometallics 2002, 21, 331-335. (b) Slugovc, C.; Burtscher, D.; Stelzer, F.; Mereiter, K. Organometallics 2005, 24, 2255-2258. (c) Fürstner, A.; Langemann, K. J. Am. Chem. Soc. 1997, 119, 9130-9136.

(13) Attempted chelate disruption using $\mathrm{Cu}$ (II) and $\mathrm{Mg}$ (II) in $\mathrm{CM}$ with 12 and 2 led to little or no improvement; $S$-Ru disruption would also mask putative privileging $S$-coordination. If so, at best, one may only expect reactivity comparable to unfunctionalized terminal olefins (very low in aqueous systems).

(14) Bernardes, G. J. L.; Chalker, J. M.; Errey, J. C.; Davis, B. G. J. Am. Chem. Soc. 2008, 130, 5052-5053.

(15) See the Supporting Information for full details.

(16) (a) Dwek, R. A. Chem. Rev. 1996, 96, 683-720. (b) Davis, B. G. Chem. Rev. 2002, 102, 579-601. (c) Ohtsubo, K.; Marth, J. D. Cell 2006, 126 , $855-867$.

(17) Harris, J. M.; Chess, R. B. Nat. Rev. Drug Discovery 2003, 2, 214-221.

(18) Antos, J. M.; Francis, M. B. Curr. Opin. Chem. Biol. 2006, 10, 253-262.

JA8026168 